\title{
PENERAPAN MODEL PEMBELAJARAN PROBLEM SOLVING UNTUK MENINGKATKAN KEMAMPUAN BERPIKIR KRITIS SISWA
}

\author{
Liska', Ahyo Ruhyanto ${ }^{2}$, Rini Agustin Eka Yanti ${ }^{3}$ \\ 1,2,3 Program Studi Pendidikan Akuntansi, Universitas Galuh JL.R.E Martadinata no. 150, Ciamis, Indonesia \\ Email: prisilialiska@gmail.com ${ }^{1}$, riniagustin.eka@gmail.com²
}

\begin{abstract}
ABSTRAC
There are still students who have not maximally achieved the Minimum Completeness Criteria (KKM) is one of the problems in this study. because the value or result is a measure of success in the learning process, in this case the teacher is required to be able to develop various learning models, the teacher must be good at choosing and using learning models in delivering teaching materials to students, in accordance with the objectives of this study To find out the difference between students' critical thinking skills using problem solving learning models and those using conventional learning methods in the final measurement. The research method used is Quasi Experimental Design Nonequivalent Control Group Design. The collection technique is carried out through observation, documentation and data analysis techniques are carried out by the product moment correlation test then analyze the correlation coefficient with the validity and normality test, injutk the hype test using the t test formula and N-Gain test. The population consisted of 44 students of class XI IPS and all of them were used as samples. Based on the results of the study, it can be concluded that there are differences in students' critical thinking skills using problem solving learning models and those using conventional learning methods in the final measurement. The application of problem solving learning models in economic subjects at MA Nurul Huda Ngenol is categorized as very good
\end{abstract}

Keywords: Problem Solving Learning Model, Critical Thinking.

\begin{abstract}
ABSTRAK
Masih adanya siswa yang belum maksimal mencapai nilai Kriteria Ketuntasan Minimal (KKM) merupakan salah satu masalah dalam penelitian ini, karena nilai atau hasil merupakan tolak ukur keberhasilan dalam proses pembelajaran, maka dalam hal ini guru dituntut untuk mampu mengembangkan berbagai model pembelajaran, guru harus pandai memilih dan menggunakan model pembelajaran dalam penyampaian materi ajar kepada siswa, sesuai dengan tujuan dari penelitian ini : Untuk mengetahui perbedaan kemampuan berpikir kritis siswa yang menggunakan model pembelajaran problem solving dengan yang menggunakan metode pembelajaran konvensional pada pengukuran akhir. Metode penelitian yang digunakan adalah Quasi Experimen Design Nonequivalent Control Group Design. Teknik pengumpulan data yang dilakukan dengan melalui observasi, dokumentasi dan tes. Teknik analisis data dilakukan dengan uji korelasi product moment kemudian menganalisis koefisien korelasi dengan uji validitas dan normalitas, dilanjutkan dengan uji hipotesis dengan menggunakan rumus uji t dan uji N-Gain. Populasi terdiri dari 44 orang siswa kelas XI IPS dan semuanya digunakan sebagai sampel. Berdasarkan hasil penelitian dapat disimpulkan bahwa terdapat perbedaan kemampuan berpikir kritis siswa yang menggunakan model pembelajaran problem solving dengan yang menggunakan metode pembelajaran konvensional pada pengukuran akhir. Penerapan model pembelajaran problem solving pada mata pelajaran ekonomi di MA Nurul Huda Ngenol berkategori sangat baik.
\end{abstract}

Kata kunci: Model Pembelajaran Problem Solving, Berpikir Kritis.

Cara sitasi: Liska., Ruhyanto A., \& Yanti, R. A. E. (2021). Penerapan Model Pembelajaran Problem Solving Untuk Meningkatkan Kemampuan Berfikir Kritis Siswa. J-KIP (Jurnal Keguruan dan IImu Pendidikan), 2 (3), 161-170. 


\section{PENDAHULUAN}

Seiring dengan perkembangan ilmu pengetahuan dan teknologi yang semakin pesat, menyababkan perubahan hampir disemua bidang kehidupan. Sejalan dengan perkembangan tersebut berdampak langsung pada persiangan global yang semakin erat, sehingga diperlukan sumber daya manusia yang berkualitas. Upaya untuk menghasilkan sumber daya manusai yang baik yaitu dengan mengembangkan mutu pendidikan. Pendidikan merupkan suatu proses jangka panjang yang sudah menjadi bagian yang tidak terpisahkan dalam kehidupan, semua hanya melalui proses pendidikan yang baik maka manusia mampu meraih dan menguasai ilmu pengetahuan untuk bekal hidupnya, dengan melalui proses pendidikan yang baik tentu dapat menciptakan mutu kualitas pendidikan maupun mutu siswa yang baik.

Tujuan pendidikan adalah tercapainya suatu hasil belajar siswa setelah terselenggaranya proses pembelajaran. Proses pembelajaran sangat mempengaruhi kemampuan berpikir kritis siswa, sehinga dalam proses pembelajaran pendidik diharapkan dapat memberikan stimulus kepada siswa untuk mengembangkan kemampuan berpikir tingkat tinggi atau berpikir kritis. Kemampuan berpikir kritis penting dimiliki oleh siswa baik di sekolah maupun di kehidupan sehari-hari. Siswa yang memiliki kemampuan berpikir kritis merupakan model untuk bisa memecahkan masalah yang terjadi didalam kehidupannya, karena menurut Robert Ennis dalam Fisher (2012) berpikir kritis adalah pemikiran yang masuk akal dan reflektif yang berfokus untuk memutuskan apa yang mesti dipercaya atau dilakukan. Berpikir kritis juga memiliki bebeapa manfaat April dalam Prameswari, Suharno \& Sarwanto, (2018) mengemukakan manfaat berfikir kriris yaitu : Memiliki banyak alternatif jawaban dan ide kreatif, mudah memahami sudut pandang orang lain, menjadi rekan kerja yang baik, lebih mandiri Sering menemukan peluang baru, meminimalkan salah persepsi, tidak mudah ditipu. Berpikir kritis juga sangat penting bagi kehidupan dan pendidikan, berpikir kritis memungkinkan pembaca untuk menilai bukti terhadap apa yang dibaca dan dapat mengidentifikasi penalaran palsu atau tidak logis. Berpikir kritis juga akan membantu untuk membuat argumen yang kuat (misalnya, dalam penugasan). Ini berarti akan melihat dan membenarkan setiap klaim yang dibuat berdasarkan bukti yang telah di evaluasi.

Menurut Maelani, Yanti \& Sutendy (2021) Pembelajaran merupakan suatu sistem yang terdiri dari berbagai komponen yang saling berhubungan. Komponen tersebut meliputi: tujuan, materi, metode dan evaluasi. Keempat komponen pembelajaran tersebut harus diperhatikan oleh guru dalam memilih dan menentukan media, model strategi dan pendekatan apa yang akan digunakan dalam kegiatan pembelajaran.

Berdasarkan hasil wawancara di MA Nurul Huda Ngenol bahwa proses pembelajaran dikelas XI masih menggunakan metode konvensional yaitu metode ceramah sehingga tidak memfasilitasi berbagai cara belajar. Hal ini terlihat pada hasil ulangan harian siswa yang rendah dan ada yang tidak tuntas. Berikut merupakan data awal rata-rata ulangan harian pada mata pelajaran ekonomi.

Tabel 1. Hasil Penilaian Akhir Semester Mata Pelajaran Ekonomi Kelas XI IPS MA Nurul Huda Ngenol Tahun Ajaran 2020/2021

\begin{tabular}{ccccccccccc}
\hline No & Kelas & $\begin{array}{c}\text { Jumlah } \\
\text { Siswa }\end{array}$ & KKM & Tinggi & Rendah & $\begin{array}{c}\text { Rata- } \\
\text { rata }\end{array}$ & Tuntas & $\%$ & Tidak & $\%$ \\
1 & XI IPS 1 & 24 & 70 & 85 & 44 & 69,83 & 13 & 54 & 11 & 46 \\
2 & XI IPS 2 & 20 & 70 & 82 & 40 & 62,4 & 11 & 55 & 9 & 45 \\
\hline
\end{tabular}

Sumber : Daftar Nilai Siswa Kelas XI IPS MA Nurul Huda Ngenol Tahun Ajaran 2020/2021

Berdasarkan tabel 1 dapat di deskripsikan bahwa kelas XI IPS di MA Nurul Huda Ngenol terdapat 2 kelas dengan jumlah siswa 44 siswa, yaitu kelas XI IPS 1 sebanyak 24 siswa dan XI IPS 2 sebanyak 20 siswa. Apabila dilihat dari penilaian PAS pelajaran ekonomi pada setiap kelasnya masih banyak siswa yang belum mencapai kriteria ketuntasan minimum (KKM). Nilai KKM untuk mata pelajaran ekonomi adalah 70. Jumlah siswa yang mendapatkan nilai diatas KKM sebanyak 24 siswa, 
dan sisanya 20 siswa mendapatkan nilai dibawah KKM. Kelas XI IPS 1 nilai tertinggi 85 dan terendah 44, nilai rata-rata 69,83, siswa yang mendapatkan nilai diatas KKM sebanyak 13 orang dan sisanya 11 siswa mendapatkan nilai dibawah KKM. Sedangkan kelas XI IPS 2 nilai tertinggi 82 dan terendah 40, nilai rata-rata 62,4, siswa yang mendapatkan nilai diatas KKM 11 orang dan sisanya 9 siswa mendapatkan nilai dibawah KKM.

Berdasarkan tabel 1 juga masih terlihat hasil belajar siswa ada yang belum mencapai KKM yang sudah ditentukan. Luasnya materi dalam pembelajaran ekonomi menuntut guru harus banyak mengembangkan sistem pembelajaran yang efektif dan efisien sehingga siswa dapat lebih memahami pelajaran yang disampaikan. Salah satu upaya yang dapat dilakukan dalam mengembangkan sistem pembelajaran yang baik yaitu dengan menggunakan media pembelajaran.

Berkaitan dengan pembelajaran ekonomi, ekonomi merupakan serangkaian aktivitas guru dalam memberikan pengajaran terhadap siswa untuk membangun konsep-konsep dan prisisp-prinsip ekonomi dengan kemampuan sendiri. Ekonomi merupakan salah satu disipiln ilmu yang dapat meningkatkan kemampuan berpikir, berargumen, memberikan kontribusi dalam kehidupan sehari-hari dan dalam dunia kerja, serta memberi dukungan dalam pengembangan ilmu pengetahuan.

Berdasarkan kondisi tersebut sebaiknya pendidik dapat memberdayakan kemampuan berpikir kritis siswa dalam pembelajaran ekonomi. Siswa harus terbiasa bertanya dan berpendapat sehingga dalam proses pembelajaran diharapkan dapat lebih bermakna. Rendahnya kemampuan berpikir kritis siswa dikarenakan belum optimalnya penggunaan variasi model pembelajaran yang digunakan oleh guru dalam mengembangkan dan menggunakan model pembelajaran, sebagian siswa belum mengikuti pembelajaran secara serius, dan rendahnya aktifitas siswa pada mata pelajaran ekonomi.

Mengahadapi permasalahan diatas, diperlukan solusi agar pembelajaran menjadi lebih baik, salah satu cara yang dapat menyelesaikan permasalahan tersebut adalah dengan menggunakan model pembelajaran. Salah satu model yang akan digunakan dalam penelitian ini adalah model pembelajaran problem solving. Model pembelajaran ini adalah salah satu dasar teoritis dari berbagai strategi pembelajaran yang menjadikan masalah sebagai salah satu isu utamanya. Model pemecahan masalah ini merupakan model pembelajaran yang berupaya membahas permasalahan untuk mencari jawaban. Irawati (2014) menyebutkan langkah-langkah pembelajaran problem solving yaitu: Memahami masalah, merancang solusi, melaksanakan solusi dan review. Meskipun model pembelajaran problem solving sangat baik digunakan untuk meningkatkan kemampuan berpikir kritis siswa tetapi model ini memiliki kekurangn dan kelebihan. Astuti (2017) mengemukakan kelebihan dan kekurang model pembelajaran problem solving yaitu: Kelebihannya 1) Model problem solving dapat membuat pendidikan di sekolah menjadi lebih relevan dalam kehidupan, khususnya dengan dunia kerja. 2) Proses belajar mengajar malului pemecahan masalah dapat membiasakan para siswa menghadapi masalah secara terampil, apabila menghadapi permasalahan di keluarga, dan bekerja kelak, suatu lkemampuan yang bermakna bagi kehidupan manusia. 3) Model problem solving dapat merangsang pengembangan kemampuan berfikir siswa secara kreatif, kritis dan menyeluruh karena dalam proses belajarnya siswa banyak melakukan mental dengan menyoroti permasalahan dari berbagai segi dalam rangka mencari pemecahan. Sedangkan kekurangannya yaitu 1) Menentukan sutu masalah yyang tingkat kesulitannya sesuai dengan tingkat berfikir siswa, tingkat sekolah dan kelasnya serta pengetahuan dan pengalaman yang telah dimiliki siswa, sangat memerlukan kemampuan dan keterampilan guru. 2) Proses belajar mengajar dengan menggunakan dan menerima informasi dari guru menjadi belajar dan banyak berfikir memecahkan permasalahan sendiri atau kelompok, yang kdang kadang memerlukan berbagai sumber belajar, merupakan kesulitan tersendiri bagi siswa.

Penelitian ini juga di dukung dengan penelitian sebelumnya yaitu pada penelitian terdahulu yang relevan diantaranya penelitian (Astuti, 2017), (Ningrum, 2019), (Ariyanto, 2018), dan (Ristiasari, Priyono \& Sukaesih, 2012). Penelitian tersebut menyatakan bahwa terdapat perbedaan yang signifikan untuk meningkatkan kemampuan berpikir kritis siswa. Ada juga penelitian terdahulu dari (Hodiyanto, 2017) dan (Tampubolon \& Sitindaon, 2013). Penelitian ini menyebutkan bahwa model pembelajaran 
problem soolvingbisa meningkatkan hasil belajar siswa dan kemampuan komunikasi matematis. Tetapi perbedaannya dalam penelitian yang ini meneliti bahwa model pembelajaran problem solving dapat meningkatkan kemampuan berpikir kritis siswa.

Dalam upaya meningkatkan berfikir kritis siswa pada mata pelajaran ekonomi, siswa membutuhkan aktifitas belajar yang lebih efektif. Aktivitas belajar siswa dalam belajar ekonomi masih rendah, siswa masih kurang dapat mengoptimalkan potensi yang dimilikinya untuk melakukan aktivitas belajar dengan baik. Dalam hal ini siswa cenderung hanya menerima pelajaran, kurang memiliki keberanian dalam menyampaikan gagasan. Hal ini dikarenakan ekonomi merupakan pelajaran yang sebagian materinya menuntut pemahaman.

Untuk mengatasi masalah tersebut perlu adanya pembaharuan dan inovasi dalam belajar mengajar. Salah satunya adalah dengan menerapkan model pembelajaran problem solving terhadap berpikir kritis siswa. Dalam model pembelajaran ini akan mengarahkan siswa untuk lebih aktif, baik dalam berdiskusi, tanya jawab, mencari jawaban, menjelaskan dan juga menyimak materi ajar.

Berdasarkan uraian diatas, penulis tertarik untuk melakukan penelitian dengan judul "Penerapan Model Pembelajaran Problem Solving Untuk Meningkatkan Kemampuan Berpikir Kritis Siswa (Studi Quasi Eksperimen Pada Mata Pelajaraan Ekonomi Kompetensi Dasar Menganalisis Perpajakan pada Pembangunan Ekonomi Kelas XI IPS MA Nurul Huda Ngenol Kecamatan Cigalontang Kabupaten Tasikmalaya)."

Berdasarkan rumusan masalah yang terdapat dalam penelitian ini, maka tujuan yang hendak dicapai adalah: 1) Untuk mengetahui perbedaan kemampuan berpikir kritis siswa yang menggunakan model pembelajaran problem solving pada pengukuran awal dan akhir di kelas eksperimen. 2) Untuk mengetahui perbedaan kemampuan berpifkir kritis siswa yang menggunakan metode pembelajaran konvensional pada pengukuran awal dan akhir di kelas kontrol. 3) Untuk mengetahui perbedaan kemampuan berpikir kritis siswa yang menggunakan model pembelajaran problem solving dengan yang menggunakan metode pembelajaran konvensional pada pengukuran akhir.

\section{METODE PENELITIAN}

Desain yang digunkan dalam penelitian adalah Quasi Experimen Design Nonequivalent Coontrol Group Design, Desain ini hampir sama dengan preetest posttest control group desain, hanya pada desain ini kelompok eksperimen maupun kontrol tidak di pilih secara random (Sugiyono, 2017).

Tabel 2. Desain Eksperimen

\begin{tabular}{lccc}
\hline \multicolumn{1}{c}{ Kelompok } & Pre Test & Perlakuan & Post Test \\
\hline Eksperimen $(\mathrm{E})$ & $\mathrm{Q} 1$ & $\mathrm{X}$ & $\mathrm{Q} 2$ \\
\hline Kontrol $(\mathrm{K})$ & $\mathrm{Q} 3$ & & $\mathrm{Q} 4$ \\
\hline
\end{tabular}

Yang menjadi variabel independen dari variabel ini yaitu model pembelajaran problem solving sedangkan variabel dependen atau terkait yaitu kemampuan berpikir kritis.

Tabel 3. Populasi Siswa Kelas XI IPS MA Nurul Huda Ngenol

\begin{tabular}{lccc}
\hline \multirow{2}{*}{ Kelas } & \multicolumn{2}{c}{ Banyaknya } & \multirow{2}{*}{ Jumlah Siswa } \\
\cline { 2 - 3 } & Laki-Laki & Perempuan & \\
\hline XI IPS 1 & 13 & 11 & 24 \\
\hline XI IPS 2 & 10 & 10 & 20 \\
\hline ber : Data Siswa Kelas XI IPS MA Nurul Huda Ngenol Tahun Ajaran 2020/2021
\end{tabular}

Karena semua populasi dijadikan sampel maka penentuan sampel dilakukan dengan menggunakan teknik "sampling jenuh". Berdasarkan data populasi maka kelas XI IPS 1 dijadikan kelas 
eksperimen dan kelas XI IPS 2 dijadikan kelas kontrol. Kelas eksperimen diberi model pembelajaran problem solving dan kelas kontrol diberi metode pembelajaran konvensional.

Data yang digunakan dalam penelitian ini data primer dan data sekunder, data primer adalah data yang langsung dikumpulkan oleh peneliti dari sumber pertamanya. Teknik yang digunakan dalam mengumpulkan data primer yaitu dengan melaksanakan kegiatan tes berpikir kritis siswa yang diperoleh dari kegiatan pengukuran awal (pretest) dan pengukuran akhir (posttest) pada kelas eksperimen dan kelas kontrol. Sedangkan data sekunder dikumpulkan peneliti dari informasi atau sumber yang telah ada di MA Nurul Huda Ngenol.

Dalam memperoleh data-data, penulis menggunakan beberapa teknik pengumpulan data yaitu: (1) Observasi (2) Dokumentasi. (3) Tes. berikut:

Dalam penelitian ini langkah-langkah yang digunakan untuk teknik analisis data adalah sebagai

1. Uji Instrumen Penelitian

a. Uji Validitas

Dengan rumus $r_{x y}=\frac{N \sum X Y-\left(\sum X\right)\left(\sum Y\right)}{\sqrt{\left\{N \sum x^{2}-\left(\sum X\right)^{2}\right\}\left\{N \sum Y^{2}-\left(\sum Y\right)^{2}\right\}}}$

b. Uji Reabilitas

Dengan rumus $r_{11}=\left(\frac{n}{n-1}\right)\left(\frac{s_{t}{ }^{2}-\sum p q}{s_{t}{ }^{2}}\right)$

c. Uji Indeks Kesukaran

Dengan rumus $I=\frac{B}{N}$

d. Uji Analisi Daya Beda

Dengan rumus $D=\frac{B_{A}}{J_{A}}-\frac{B_{B}}{J_{B}}$

2. Uji Prasyarat Analisi Data

a. Uji Homogenitas

Dibawah ini merupakan langkah-langkah yang dilakukan dalam uji homogenitas

1) Membuat tabel perhitungan perbedaan antara pretest kelas eksperimen dan pretest kelas kontrol

2) Menentukan mean atau rata-rata

3) Menentukan simpangan baku

4) Menentuan nilai thitung dengan menggunakan t-test

5) Menentukan derajat kebebasan (dk)

6) Mencari nilai tabel

7) Membandingkan nilai thitug dengan tabel dengan kriteria dalam pengujian.

b. Uji Normalitas

Salah satu uji prasyarat untuk memenuhi asumsi kenormalan dalam analisis data, untuk menggunakan uji normalitas menggunakan rumus Uji Liliefors.

c. Uji Analisis Data

Uji analisis data ini dilakukan untuk:

1) Untuk mengetahui peningakatan kemampuan berpikir kritis siswa yang menggunakan model pembelajaran problem solving pada pengukuran awal (pretest) dan pengukuran akhir (posttest) di kelas eksperimen.

2) Untuk mengetahui peningkatan kemampuan berpikir kritis siswa yang menggunakan metode konvensional pada pengukuran awal (pretest) dan pengukuran akhir (posttest) di kelas kontrol.

3) Untuk mengetahui perbedaan kemampuan berpikir kritis siswa yang menggunakan model pembelajaran problem solving dengan yang menggunakan mtode pembelajaran konvensional pada pengukuran akhir. 


\section{HASIL PENELITIAN DAN PEMBAHASAN Hasil Penelitian}

Analisis data kuantitaif dalam penelitian ini digunakan untuk menjabarkan hasil penelitian dalam bentuk perhitungan angka yang mana diterapkan dengan menggunakan rumus-rumus statistik. Analisis data kuantitatif yang digunakan dalam penelitian ini adalah Analisis Korelasi Product Moment.

Analisis Korelasi Product Moment digunakan untuk mengetahui derajat atau kekuatan hubungan antara variabel $X$ (Model Pembelajaran Problem Solving) dengan variabel $Y$ (Kemampuan Berpikir Kritis Siswa).

Berdasarkan hasil penelitian, deskripsi perbedaan Kemampuan Berpikir Kritis siswa yang menggunakan Model Pembelajran Problem Solving pada Pengukuran awal (pretest) dan Pengukuran akhir (posttest), dikelas eksperimen diperoleh data sebagai berikut:

Tabel 4. Rekapitulasi Hasil Pretest dan Postes Kelas Eksperimen

\begin{tabular}{cccc}
\hline Keterangan & Pretest & Posttest & Gain \\
\hline Jumlah sampel & 24 & 24 & 24 \\
Nilai Tertinggi & 71,43 & 100 & 50 \\
Nilai Terendah & 42,85 & 78,57 & 28,57 \\
Nilai Rata-rata & 53,57 & 90,47 & 36,90 \\
\hline \multicolumn{3}{l}{ Sumber:data di olah oleh peneliti, 2021 }
\end{tabular}

Berdasarkan tabel 4 diperoleh data pada pengukuran awal (pretest) kelas eksperimen dengan jumlah sampel 24 orang siswa, nilai tertinggi sebesar 71,43 dan nilai terendah sebesar 42,85, sedangkan untuk rata-ratanya diperoleh sebesar 53,57. Kemudian pada pengukuran akhir (posttest) dengan jumlah sampel 24 orang siswa diperoleh nilai tertinggi sebesar 100 dan nilai terendah sebesar 78,57 , sedangkan untuk rata-ratanya diperoleh sebesar 90,47. Dan untuk gain dengan jumlah sampel 23 orang siswa, nilai gain tertinggi 50 dan nilai terendahnya 28,57 sedangkan nilai rata-ratanya 36,90.Dengan demikian model pembelajaran problem solving dapat meningkatkan kemampuan berpikir kritis siswa. Dibuktikan dengan gain terbesar 50 dan N-Gain 0,81 berkategori tinggi.

Berdasarkan hasil penelitian, deskripsi perbedaan Kemampuan Berpikir Kritis siswa yang menggunakan Metode Pembelajaran Konvensional pada Pengukuran awal (pretest) dan Pengukuran akhir (posttest), dikelas eksperimen diperoleh data sebagai berikut:

\begin{tabular}{cccc} 
Tabel 5. Rekapitulasi Hasil Pretest dan Posttest & Kelas kontrol \\
\hline Keterangan & Pretest & Posttest & Gain \\
\hline Jumlah sampel & 20 & 20 & 20 \\
Nilai Tertinggi & 71,43 & 85,71 & 35,72 \\
Nilai Terendah & 35,71 & 71,43 & 14,28 \\
Nilai Rata-rata & 51,78 & 78,21 & 26,43 \\
\hline
\end{tabular}

Berdasarkan tabel 5 diperoleh data pada pengukuran awal (pretest) kelas kontrol dengan jumlah sampel 20 orang siswa, nilai tertinggi sebesar 71,43 dan nilai terendah sebesar 35,71 , sedangkan untuk rata-ratanya diperoleh sebesar 51,78. Kemudian pada pengukuran akhir (posttest) dengan jumlah sampel 24 orang siswa diperoleh nilai tertinggi sebesar 85,71 dan nilai terendah sebesar 71,43 , sedangkan untuk rata-ratanya diperoleh sebesar 78,21 . Dan untuk gain dengan jumlah sampel 20 orang siswa, nilai gain tertinggi 35,72 dan nilai terendahnya 14,28 sedangkan nilai rata-ratanya 26,43.Dengan demikian metode pembelajaran konvensional dapat meningkatkan kemampuan berpikir kritis, tetapi peningkatannya tidak signifikan. Dibuktikan dengan gain terbesar 35,72 dan N-Gain 0,55 berkategori sedang. 
Tabel 6. Rekapitulasi Hasil Perhitungan Uji Hipotesis

\begin{tabular}{cccc}
\hline Hipotesis & thitung & ttabel & Hasil Analisis \\
\hline 1 & 15,57 & 1,68 & $15,57>1,68$ \\
2 & 10,20 & 1,69 & $10,20>1,69$ \\
3 & 5,84 & 1,68 & $5,84>1,68$
\end{tabular}

Sumber: data di olah oleh peneliti, 2021

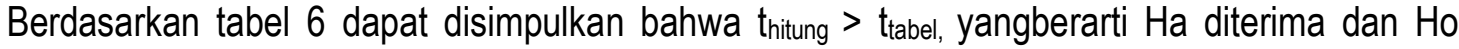
ditolak artinya terdapat perbedaan kemampuan berpikir kritis siswa menggunakan model pembelajaran problem solving pada pengukuran awal (pretest) dan pengukuran akhir (postetst) di kelas XI IPS MA Nurul Huda Ngenol.Dengan demikian model pembelajaran problem solving dapat meningkatkan kemampuan berpikir kritis siswa.

\section{Pembahasan}

1. Perbedaan Kemampuan Berpikir Kritis Siswa yang Menggunakan Model Pembelajaran Problem Solvingpada Pengukuran Awal (pretest) dan Pengukuran Akhir (posttest) di Kelas Eksperimen

Berdasarkan hasilperhitungan uji statistik, diketahui bahwa terdapat perbedaan yang signifikan kemampuan berpikir kritis siswa yang menggunakan model pembelajaran problem solving pada pengukuran awal (pretest) dan pengukuran akhir (postetst) di kelas eksperimen. Perbedaan tersebut dapat dilihat dari hasil rata-rata nilai yang diperoleh kelas eksperimen dari pengukuran awal (pretest) dan pengukuran akhir (posttest). Pada pengukuran awal siswa memperoleh nilai rata-rata 53,57 dan pada pengukuran akhir (posttest) diperoleh sebesar 90,47. Dengan demikian terdapat perbedaan yang signifikan pada pengukuran awal (pretest) dan pengukuuran akhir (posttest) di kelas eksperimen yaitu sebesar 36,9 dan N-Gain 0,81 berkategori tinggi.

Perbedaan nilai rata-rata pada pengukuran awal (pretest) dan pengukuran akhir (posttest) di kelas eksperimen membuktikan bahwa pengukuran akhir (posttest) yang dilakukan setelah pembelajaran menerapkan model pembelajaran problem solving lebih besar. Artinya bahwa model pembelajaran problem solving sangat tepat digunakkan pada mata pelajaran Ekonomi kompetensi dasar menganalisis perpajakan dalam pembungan ekonomi. Hal ini dikarenakan model pembelajaran problem solving menurut Hariyanti dalam Yusuf \& Sutiarso (2017) mempunyai beberapa kelebihan yaitu sebagai berikut:

a. Mendidik siswa untuk berfikir sistematis

b. Mampu mencari jalan keluar terhadap situasi yang dihadapi

c. Belajar menganalisis suatu masalah dari beberapa aspek

d. Mendidik siswa percaya diri sendiri

e. Berfikir dan bertindak kreatif

f. Memecahkan masalah yang dihadapi secara realitas

g. Dapat membuat pendidikan sekolah lebih relevan ddengan kehidupan, khususnya dunia kerja

h. Merangsang kemajuan perkembangan berfikir siswa untuk menyelesaikan masalah yang dihadapi dengan tepat.

Penerapan model pembelajaran problem solving belum sepenunya maksimal, karena masih terdapat beberapa kendala di lapangan misalnya manajemen waktu. Sesuai dengan yang diungkapkan oleh Hariyanti dalam Yusuf \& Sutiarso (2017) terdapat beberapa kekurangan dalam menerapkan model pembelajaran problem solving diantaranya sebagai berikut:

a. Memerlukan waktu yang cuckup banyak

b. Kemampuan siswa dalam memecahkan masalah berbeda-beda dan yang yang sempurna dalam memecahkan masalah tetapi ada juga yang kuran dalam memecahkan masalah. 
Model pembelajaran problem solving merupakan cara belajar mengajar yang dilakukan dengan cara melatih siswa untuk menghadapi berbagai masalah untuk dipecahkan sendiri maupun bersamasama dengan berkelompok. Dengan demikian siswa akan terlatih berpikir secara kritis dan apabila ada masalah maka mereka akan bisa menyelesaikannya.

\section{Perbedaan Kemampuan Berpikir Kritis Siswa Yang Menggunakan Metode Konvensional pada Pengukuran Awal (pretest) dan Pengukuran Akhir (posttest) di Kelas Kontrol}

Berdasarkan hasilperhitungan uji statistik, diketahui bahwa terdapat perbedaan yang signifikan kemampuan berpikir kritis siswa yang menggunakan metode pembelajaran konvensional pada pengukuran awal (pretest) dan pengukuran akhir (postetst) di kelas kontrol. Perbedaan tersebut dapat dilihat dari hasil rata-rata nilai yang diperoleh kelas kontrol dari pengukuran awal (pretest) dan pengukuran akhir (posttest). Pada pengukuran awal siswa memperoleh nilai rata-rata 51,78 dan pada pengukuran akhir (posttest) diperoleh sebesar 78,21. Dengan demikian terdapat perbedaan yang signifikan pada pengukuran awal (pretest) dan pengukuuran akhir (posttest) di kelas kontrol yaitu sebesar 26,43 dan N-Gain 0,55 berkategori sedang.

Peningakatan nilai rata-rata yang di peroleh siswa dengan menggunnakan metode pembelajaran konvensional kurang maksimal, karena peningkatan kemampuan berpikir kritis siswa pada kompetensi dasar menganalisis perpajakan dalam pembangunan ekonomi termasuk kategori sedang.

Upayauntuk meningkatkan kemampuan berpikir kritis siswa dengan menggunakan metode pembelajaran konvensional dapat dilakukan dengan cara menyampaikan materi pembelajaran dengan cara menarik meskipun pembelajran tetap beroriensi pada guru, serta memberikan kesempatan lebih kepada siswa untuk menanyakan materi yang belum dipahami. disamping itu guru memanfaatkan media pembelajaran yang kreatif dan menarik.

\section{Perbedaan Kemampuan Berpikir Kritis Siswa yang Menggunakan Model Pembelajaran Problem Solving dengan Metode Pembelajaran Konvensional Pada Pengukuran Akhir (posttest) di Kelas Eksperimen da Kelas Kontrol}

Perbedaan kemampuan berpikir kritis siswa yang menggunakan model pembelajaran problem solving lebih besar dibandingkan kemampuan berpikir kritis siswa yang menggunakan metode pembelajaran konvensional pada pengukuran akhir (posttest). Hal tersebut dapat dilihat dari hasil ratarata nilai yang diperoleh siswa pada pengukuran akhir (posttest) di kelas eksperimen sebesar 90,47 dengan N-Gain 0,81 berkategori tinggi dan pengukuran akhir (postest) di kelas kontrol sebesar 78,21 dengan $\mathrm{N}$-Gain sebesar 0,55 berkategori sedang.

Dengan demikian nilai rata-rata pada pengukuran akhir (posttest) di kelas eksperimen lebih besar dibandingkan dengan nilai rata-rata di kelas kontrol. Artinya model pembelajaran problem solving lebih unggul dan dapat meningkatkan kemampuan berpikir kritis siswa dibandingkan dengan metode pembelajaran konvensional. Hal ini sesuai dengan kelebihan dari model pembelajaran problem solving menurut Hariyanti dalam Yusuf \& Sutiarso (2017) yaitu sebagai berikut:

a. Mendidik siswa untuk berfikir sistematis

b. Mampu mencari jalan keluar terhadap situasi yang dihadapi

c. Belajar menganalisis suatu masalah dari beberapa aspek

d. Mendidik siswa percaya diri sendiri

e. Berfikir dan bertindak kreatif

f. Memecahkan masalah yang dihadapi secara realitas

g. Dapat membuat pendidikan sekolah lebih relevan ddengan kehidupan, khususnya dunia kerja

h. Merangsang kemajuan perkembangan berfikir siswa untuk menyelesaikan masalah yang dihadapi dengan tepat. 
Hasil penelitian juga selaras dengan penelitian sebelumnya yaitu pada penelitian terdahulu yang relevan diantaranya penelitian (Astuti, 2017), (Ningrum, 2019) dan (Ariyanto, 2018). Penelitian tersebut menyatakan bahwa terdapat pengaruh yang yang signifikan untuk meningkatkan kemampuan berpikir kritis siswa. Persamaann penelitian ini dengan penelitian terdahulu yaitu hasilnya sama menunjukan bahwa model pembelajaran problem solving dapat meningkatkan kemampuan berpikir kritis siswa sedangkan perbedaaannya dalam penelitian terdahulu yang relevan dalam penelitiannya ada yang menggunakan metode penelitian tindakan kelas (Classroom Action Research) sedangkan dalam penelitian ini menggunakan metode eksperimen. Dengan demikian meskipun metode penelitian yang digunakan berbeda tetapi hasilnya tetap sama bisa meningkatkan kemampuan berpikir kritis siswa, karena model pembelajaran problem solving itu akan melatih siswa utuk menghadapi berbagai masalah yang harus dipecahkkan baik individu maupun berkelompok.

\section{PENUTUP}

Penelitian ini dilakukan untuk mengetahui apakah Model Pembelajaran Problem solving berpengaruh terhadap Kemampuan Berpikir Kritis Siswa(Studi Eksperimen Pada Mata Pelajaran Ekonomi Kompetensi Dasar Menganalisis Perpajakan Dalam Pembangunan Ekonomi Kelas XI IPS MA Nurul Huda Ngenol Kecamatan Cigalontang Kabutpaten Tasikmalaya). Berdasarkan hasil analisis data penelitian, maka dapat ditarik simpulan sebagai berikut, bahwa:

1. Terdapat peningkatan kemampuan berpikir kritis siswa yang menggunakan model pembelajaran problem solving pada mata pelajaran ekonomi di kelas eksperimen (kelas XI IPS 1) melalui pengukuran awal (pretest) dan pengukuran akhir (posttest).

2. Terdapat peningkatan kemampuan berpikir kritis siswa yang menggunakan metode pembelajaran konvensional pada mata pelajaran ekonomi di kelas kontrol (kelas IPS 2) pada pengikuran awal (pretest) dan pengukuran akhir (postest).

3. Terdapat perbedaan kemampuan berpikir kritis siswa yang menggunakan model pembelajaran problem solving dengan kemampuan berpikir kritis siswa yang menggunakan metode pembelajaran konvensional pada pengukuran akhir (posttest) kelas eksperimen (XI IPS 1) dan kelas kontrol (XI IPS 2).

\section{REKOMENDASI}

Berdasarkan kesimpilan diatas, maka peneliti menyampaikan saran-saran sebagai berikut:

1. Penerapan model pembelajaran problem solving sebaiknya dijadikan alternatif yang dipilih oleh pendidik dalam menyampaikan materi pembelajaran dengan tetap memperhatikan berbagai faktor seperti kesiapan siswa untuk belajar, media pembelajaran, situasi kelas dan materi pelajaran yang akan dipelajari.

2. Penggunaan metode pembelajaran konvensional sebaiknya dikemas sedemikian rupa agar tidak membosankan, seperti dalam menyampaikan materi menggunakan alat bantu berupa proyektor. Pendidik harus memperbanyak tanya jawab dengan siswa agar proses pembelajaran lebih interaktif.

3. Bagi peneliti selanjutnya sebaiknya penerapan model pembelajaran problem solving harus lebih memperhatikan waktu dan materi yang tepat supaya penelitian bisa dilaksanakan tepat waktu.

\section{UCAPAN TERIMAKASIH}

Kedua orang tua tercinta, yang senantiasa mencurahkan perhatian, dukungan, kasih sayang serta do'a yang tiada hentinya dicurahkan kepada penulis demi keberhasilan dan kelancaran selama studi dan penulisan ini. Pihak sekolah MA Nurul Huda Ngenol yang telah memberikan izin penelitian dan memberikan bantuan yang tidak ternilai. 


\section{DAFTAR PUSTAKA}

Ariyanto. (2018). Penerapan Model Pembelajaran Problem solving Untuk Meningkatkan Keampuan Berfikir Kritis dan Hasil Belajar siswa. Jurnal Guru Kita (JKG). (Online), Volume 2 (https://scholar.google.com/), diakses 28 Januari 2021.

Astuti, S. S. (2017). Pengaruh Penerapan Model Pembelajaran Prolem Solving Berbentuk Media Permainan Squareuntuk Memberdayakan Kemampuan Berfikir Kritis dan Motivasi Belajar Siswa pada Mata Pelajara Ekosistem Kelas VII SMP N Bandar Lamopung. (Onlone), (https://scholar.google.com/), diakses 16 Desesmber 2020.

Fisher, A. (2012). Berfikir Kritis. Jakarta: Erlangga.

Hodiyanto. (2017). Pengaruh Model Pembelajaran Problem Solving Terhadap Kemampuan Komunikasi Matematis Ditinjau Dari Gender. (online), (https://journal.uny.ac.id/index.php/jrpm) diakses 13 Agustus 2021.

Irawati, R. K. (2014). Pengaruh Model Problem Solving dan Problem Posing serta Kemampuan Awal terhadap Hasil Belajar Siswa. (online), volume 2 (https://scholar.google.com/), diakses 15 April 2021.

Maelani, G., Yanti, R. A. E \& Sutendy, U. A. (2021). Pengaruh penerapan model pembelajaran project based learning (pbl) melalui penggunaan media unit kegiatan belajar mandiri (UKBM) terhadap hasil belajar siswa. J-KIP (Jurnal Keguruan dan Ilmu Pendidikan), 2 (2), 71-80.

Ningrum. (2019). Pengaruh Penerapan Model Pembelajaran Problem Solving terhadap Leterampilan Berfikir Kritis Siswa. (Online), (https://scholar.google.com/), diakses 16 Desember 2020.

Prameswari, S. W., Suharno., \& Sarwanto. (2018). Inculcate Critical Thinking Skills In Primary Schools. (online), volume 1 (https://scholar.google.com/), diakses 15 April 2021.

Ristiasari, T., Priyono, B., \& Sukaesih, S. (2012). Model Pembelajaran Problem Solving dengan Mind Mapping Terhadap Kemampuan Berpikir Kritis Siswa. (online). (https://journal.unnes.ac.id/sju/index.php/ujeb), diakes 13 Agustus 2021.

Sugiyono. (2017). Statistika Untuk Penelitian. Bandung. Alfabeta.

Tampubolon, T., \& Sitindaon, S. F. (2013). Pengaruh Model Pembelajaran Problem Solving Terhadap Hasil Belajar Siswa Kelas X SMA N 7 Medan. (online). Volume 1 (https://scholar.google.com/), diakses 13 Agustus 2021.

Yusuf, O. L., \& Sutiarso, S. (2017). Problem solving dalam Pemebelajaran Matematika. (online). (https://scholar.google.com/), diakses 15 April 2021. 